\title{
Factors Affecting the Choice of Renal Replacement Therapy in Patients with End Stage Renal Failure
}

\author{
Son Dönem Böbrek Yetmezliği Hastalarında Renal Replasman Tedavi Seçimini Etkileyen Faktörler
}

${ }^{1}$ Ustun Yilmaz, ${ }_{\mathbb{e}}^{1}$ Ayca Inci, ${ }^{2}$ Ayse Akarsu, ${ }^{1}$ Ummuhan Maden

'Antalya Training and Research Hospital Nephrology Clinic, Antalya, Turkey

${ }^{2}$ Ergani State Hospital, Clinic of Internal Medicine, Diyarbakir, Turkey
Correspondence:

Ustun YILMAZ

Antalya Training and Research

Hospital Nephrology Clinic, Antalya, Turkey

e-mail: ustunfy@gmail.com

\section{Abstract}

It was aimed to investigate the factors affecting the choice of renal replacement therapy by examining the data of patients with end stage renal disease, to whom we applied a predialysis education program. Patients who were started on renal replacement therapy in our clinic were evaluated retrospectively. Renal replacement therapy were divided into three groups as hemodialysis, peritoneal dialysis and renal transplantation and compared according to their clinical and demographic characteristics. The comorbidities of the patients were calculated using the 'modified charlson comorbidity index' score. There were a total of 464 patients in the study, of whom $330(71.1 \%)$ chose hemodialysis, $65(14 \%)$ peritoneal dialysis, and $69(14.9 \%)$ renal transplantation. Age was significantly different between the groups $(\mathrm{p}<0.001)$. According to the hemodialysis patients of renal transplantation patients; that the rate of being a university graduate $(\mathrm{p}<0.001)$ and never married $(\mathrm{p}=0.004)$ is higher. Rate of living in the urban area $(\mathrm{p}=0.021)$ and working patients $(\mathrm{p}=0.031)$ were higher in renal transplantation patients. The rate of diabetic nephropathy of renal etiology was lower in renal transplantation patients $(\mathrm{p}=0.014)$. When the modified charlson comorbidity index scores of the groups were examined, highest values were in the hemodialysis group and the lowest values were in the transplantation group $(\mathrm{p}<0.001)$. Patients sociodemographic characteristics and comorbid conditions were effective in the choice of renal replacement therapy modality. In addition to the educating given before the selection, most appropriate treatment modality should be selected by considering these features.

Keywords: End stage renal disease, renal replacement therapy, hemodialysis, peritoneal dialysis, renal transplantation
Prediyaliz eğitim programı uyguladığımız son dönem böbrek yetmezliği tanısı ile takip edilen hastaların verileri incelenerek renal replasman tedavisi seçimini etkileyen faktörlerin araştırılması amaçlanmıştır. Kliniğimizde takip edilen renal replasman tedavisi başlanan hastalar retrospektif olarak değerlendirildi. Renal replasman tedavisi hemodiyaliz, periton diyalizi ve böbrek transplantasyonu olmak üzere üç gruba ayrılarak bu gruplar arasında hastalar klinik ve demografik özelliklerine göre karşılaştırıldı. Hastaların komorbidite düzeyleri 'modifiye charlson komorbidite indeksi' skoru kullanılarak hesaplandı. Çalıșmada 330'u $(\% 71,1)$ hemodiyaliz, 65'i (\%14) periton diyalizi ve 69'u $(\% 14,9)$ böbrek nakli grubunda olmak üzere toplam 464 hasta vardı. Gruplar arasında yaş anlamlı olarak farklıydı $(\mathrm{p}<0,001)$. Böbrek nakli yapılan hastaların hemodiyaliz hastalarına göre; üniversite mezunu oranının $(\mathrm{p}<0,001)$ ve hiç evlenmemiş $(\mathrm{p}=0,004)$ olma oranlarının daha yüksek olduğu bulunmuștur. Renal transplantasyon hastalarında kentsel alanda yaşama oranı $(\mathrm{p}=0,021)$ ve çalışan hasta oranı $(\mathrm{p}=0,031)$ daha yüksekti. Renal transplantasyon hastalarında böbrek hastalığı etiyolojisinin diyabetik nefropati olma oranı daha düşüktü. Grupların modifiye charlson komorbidite indeksi skorları incelendiğinde en yüksek değerlerin hemodiyaliz grubunda olduğu ve en düsük değerlerin ise transplantasyon grubunda olduğu tespit edilmiştir $(\mathrm{p}<0.001)$.Hastarın sosyodemografik özelliklerinin ve komorbid durumlarının renal replasman tedavi modalitesinin seçiminde etkili olduğu görülmüştür. Seçim öncesi verilen eğitimin yanında bu özellikler de dikkate alınarak en uygun tedavi modalitesi seçilmelidir.

Anahtar Kelimeler: Son dönem böbrek yetmezliği, renal replasman tedavisi, hemodiyaliz, periton diyalizi, renal transplantasyon

Received 07.01.2022 Accepted 28.01.2022 Online published 28.01.2022 


\section{Introduction}

Chronic Kidney Disease (CKD) is an important public health problem that has become an epidemic all over the world and in Turkey $(1,2)$. Since the awareness of CKD is very low, there are serious delays in diagnosis and treatment. The prevalence of CKD in adults in our country is $15.7 \%$ (3). CKD requires a well-rounded treatment plan that affects many aspects of daily life, including diet and fluid intake. CKD patients who have reached the level of end stage renal disease (ESRD) need renal replacement therapy (RRT) in order to maintain their lives at the best level. ESRD is a disease that quickly leads to death if one of the RRT is not started. RRT options in these patients; consists of hemodialysis (HD), peritoneal dialysis (PD) and renal transplantation (RT). The use of RRT methods varies considerably between countries and centers (4). Although kidney transplantation is the treatment of choice for eligible ESRD patients, dialysis is the predominant treatment in most countries (5). While kidney transplantation is associated with the best survival, there are limitations due to possible transplantation incompatibility and lack of donor kidneys. Therefore, most of the patients are faced with evaluating the HD or PD option (6). More than $80 \%$ of the world's dialysis population receives conventional, facility based, three times a week HD treatment (6). On the other hand, there is a significant growth in the use of PD therapy for RRT in developing countries (7). All RRT have different advantages and disadvantages. Compared with HD, PD is associated with increased patient autonomy and flexibility (8). But it does require patients to learn technical skills and take a degree of responsibility for self care. HD treatment can be a restrictive treatment method as patients have to come to the center 3 days a week and receive 4 hours of treatment. However, the treatment is carried out by trained nurses without requiring patient responsibility. In studies on dialysis modalities, it is controversial which dialysis modality is superior in terms of patient survival $(9,10)$. Therefore, it must be acknowledged that there is no single perfect form of RRT. Each of the available options has its own unique challenges and advantages.

It is not easy to identify the most appropriate RRT scheme for ESRD patients. In this case, decisions are tailored to each patient's values and preferences. These patients consider independence, quality and quantity of life, and flexibility in the daily schedule important (11).

It has been reported that many factors such as the experience of the center, the age of the patient, the comorbid conditions, the education status of the patient, socioeconomic conditions, treatment reimbursement policies, physician attitudes, the problem of accessing hospital dialysis beds, quality of life, and the education given to the patient during the predialysis period are effective in the selection of RRT (12-15).

The choice of ESRD treatment modality is complex, but of fundamental importance because it affects both costs and patient clinical outcomes. For this reason, it is important to determine the effective factors in the selection of RRT.

In this study; The factors affecting the choice of RRT were evaluated by examining the data of the patients who started RRT with followup in our clinic, where we applied a predialysis educating program.

\section{Material and Method}

\section{Study design}

This study was designed as a single center and retrospective analysis of patients data.The patients diagnosed with ESRD who were followed up at the nephrology clinic at the Antalya Training and Research Hospital. This study was approved by the Ethics Committee of the Scientific Research Ethics Committee of Antalya Training and Research Hospital (Approval number: 18/27) and was conducted in accordance with the ethical standards defined in the 1964 Helsinki declaration. 


\section{Patients}

The data of 464 patients (192 women and 272 men) who were followed up in the Nephrology Clinic of Antalya Training and Research Hospital and started RRT due to ESRD were evaluated. Patients with estimated glomerular filtration rate (eGFR) $\leq 15$ $\mathrm{ml} / \mathrm{min} / 1.73 \mathrm{~m}^{2}$ were considered as ESRD using the 'chronic kidney disease epidemiology collaboration' (CKD-EPI) formula (16). The patients were divided into 3 groups according to the preferred type of RRT (HD, PD, RT) and compared according to their clinical and demographic characteristics. Comorbidities of the patients were calculated using the 'modified charlson comorbidity index' (MCCI) score. Comorbidity was classified as low (score $\leq 3$ ), moderate (scores 4 and 5), high (scores 6 and 7) and very high comorbidity (score $\geq 8$ ) (17). Patients who were diagnosed with ESRD, had their first maintenance RRT planned, were 18 years of age or older, and were able to communicate verbally, who received training on RRT during the predialysis period were included in the study. ESRD patients under 18 years of age who were transferred from other centers after starting RRT, re-started other RRT after rejection of the kidney graft, and were excluded from the study.

\section{Statistical analysis}

Descriptive statistics are presented with $\mathrm{n}(\%)$, median(min-max), and mean \pm standard deviation (SD). Shapiro Wilks test was used to control the normality assumption. Pearson chi-square test was used to analyze the relationships between categorical variables. The Kruskal Wallis test was used for the nonparametric comparison of the difference between the measurement values of the groups, the Bonferroni-Dunn test was used as the post-hoc test for the significant cases, while the One-Way ANOVA and post-hoc Tukey HSD test were used for the parametric comparisons. Analyzes were made with the SPSS (Statistical Package for Social Science) for Windows 22.0 package program. P values less than 0.05 were considered statistically significant.

\section{Results}

Of the 464 patients who started RRT due to ESRD, followed in the Nephrology clinic of Antalya Training and Research Hospital, 272 $(58.6 \%)$ were male and $192(41.4 \%)$ were female. The mean age was $57.9 \pm 14.1$ years. In the etiology of ESRD; diabetic nephropathy $(\mathrm{DN})$ was detected in 175 (38\%) patients, hypertensive nephropathy (HN) in 101 $(21.9 \%)$ patients, and polycystic kidney disease (PKD) in $40(8.7 \%)$ patients, while $145(31.5 \%)$ patients had etiology of ESRD could not be determined. The clinical and demographic characteristics of the patients are listed in table 1.

Table 1. Clinical and demographic characteristics of the patients

\begin{tabular}{lc}
\hline & $\mathrm{n}: 464$ \\
Age (year), mean \pm SD & $57,9 \pm 14,1$ \\
Gender, n(\%) & $192(41,4)$ \\
$\quad$ Female & $272(58,6)$ \\
$\quad$ Male & $166,2 \pm 9,4$ \\
Height (cm), mean \pm SD & $76,7 \pm 17,7$ \\
Weight (kg), mean \pm SD & \\
Education status, $\mathbf{n}(\%)$ & $76(16,7)$ \\
$\quad$ Illiterate & $15(3,3)$ \\
Literate & $247(54,3)$ \\
Elementary school & $43(9,5)$ \\
\hline
\end{tabular}




\begin{tabular}{|c|c|}
\hline High school & $42(9,2)$ \\
\hline University & $32(7)$ \\
\hline \multicolumn{2}{|l|}{ Marital status, n(\%) } \\
\hline Never married & $20(5,7)$ \\
\hline Married & $282(80,3)$ \\
\hline Widow & $49(14)$ \\
\hline \multicolumn{2}{|l|}{ Home partner status, n(\%) } \\
\hline Lives alone & $23(6,6)$ \\
\hline Lives with partner & $56(16)$ \\
\hline Lives with partner and children & $210(60)$ \\
\hline Lives with children & $22(6,3)$ \\
\hline Lives with parents & $15(4,3)$ \\
\hline Other (Carer) & $24(6,9)$ \\
\hline \multicolumn{2}{|l|}{ Settlement unit, n(\%) } \\
\hline Rural & $208(45,1)$ \\
\hline Urban & $253(54,9)$ \\
\hline \multicolumn{2}{|l|}{ Working status, n(\%) } \\
\hline Working & $80(22,6)$ \\
\hline Not working & $148(41,8)$ \\
\hline Retired & $100(28,2)$ \\
\hline Other (irregular business) & $26(7,3)$ \\
\hline \multicolumn{2}{|l|}{ Visual impairment, n(\%) } \\
\hline Yes & $158(49,5)$ \\
\hline No & $161(50,5)$ \\
\hline \multicolumn{2}{|l|}{ RRT modality, n(\%) } \\
\hline HD & $330(71,1)$ \\
\hline PD & $65(14)$ \\
\hline RT & $69(14,9)$ \\
\hline
\end{tabular}

Kidney disease etiology, n(\%)

$\begin{array}{lc}\text { DM } & 175(38) \\ \text { HT } & 101(21,9) \\ \text { PKD } & 40(8,7) \\ \text { Others } & 145(31,5)\end{array}$

Family history of kidney disease, n(\%)

Yes

No

$421(91,1)$

Number of people living at home, median (minmax)

Predialysis educating period (month),

$16(1-108)$ median (min-max)

Number of annual follow up, n(\%)

$<3$

Modified charlson comorbidity index score, median $5(1-11)$

(min-max)

SD: standard deviation, RRT: renal replacement therapy, HD: hemodialysis, PD: peritoneal dialysis, $R T$ : renal transplantation, DM: diabetes mellitus, HT: hypertension, PKD: polycystic kidney disease 
The clinical and demographic characteristics of the patients were compared according to the type of RRT. According to the type of RRT, 330 (71.1\%) HD, 65 (14\%) PD patients and $69(14.9 \%)$ RT patients were detected. The mean age was $62 \pm 13$ in those who chose HD treatment, $54 \pm 12$ in those who chose PD, and $44 \pm 14$ in those with RT. Age was found to be significantly different between the groups $(p<0.001)$. When their education levels were compared, it was determined that 14 (4.3\%) HD patients, 5 (7.7) patients with PD and $13(19.1 \%)$ RT patients were university graduates. Accordingly, it was determined that the percentage of being a university graduate in the RT group was higher than in the HD group $(p<0.001)$. When the marital status of the patients was examined, it was determined that the never married patients were $9(3.6 \%)$ in the HD group, $3(5.9 \%)$ in the PD group, and $8(16 \%)$ in the RT group. Accordingly, the percentage of never married was found to be higher in the RT group than in the HD group $(p=0.004)$. The percentage of patients in the RT group living in the urban area was found to be higher than the other two groups $(\mathrm{p}=0.021)$. The percentage of patients working in the RT group was higher than in the other two groups $(p=0.031)$. While the rate of kidney disease etiology being $\mathrm{DN}$ was lower in RT patients than the other two groups, it was determined that the rate of being in other etiologic categories was higher $(p=0.014)$. It was determined that the modified charlson comorbidity index scores of all groups were statistically different. When the modified charlson comorbidity index scores of the groups were examined, it was determined that the highest values were in the HD group and the lowest values were in the RT group $(\mathrm{p}<0.001)$. (Table 2$)$.

In comparison; gender $(\mathrm{p}=0.251)$, height $(p=0.783)$, weight $\quad(p=0.862)$, visual impairment $(\mathrm{p}=0.149)$, family history of kidney disease $(p=0.135)$, number of people living at home $(p=0.309)$, It was found that there was no significant difference between the RRT groups in terms of the months of education during the predialysis period $(p=0.258)$ and the number of annual follow up $(\mathrm{p}=0.847)$ (Table 2).

Table 2. Comparison of the clinical and demographic characteristics of the patients according to the type of renal replacement therapy

\begin{tabular}{|c|c|c|c|c|}
\hline Age (year), mean \pm SD & $\begin{array}{c}\text { HD } \\
\mathrm{N}: 330 \\
62 \pm 13^{\mathrm{a}}\end{array}$ & $\begin{array}{c}\mathrm{PD} \\
\mathrm{N}: 65 \\
54 \pm 12^{\mathrm{b}}\end{array}$ & $\begin{array}{c}\text { RT } \\
\text { N:69 } \\
44 \pm 14^{\mathrm{c}}\end{array}$ & $\begin{array}{c}\mathbf{p} \\
<0,001\end{array}$ \\
\hline \multicolumn{5}{|l|}{ Gender, n(\%) } \\
\hline Female & $144(43,6)$ & $25(38,5)$ & $23(33,3)$ & \multirow{2}{*}{0,251} \\
\hline Male & $186(56,4)$ & $40(61,5)$ & $46(66,7)$ & \\
\hline Height $(\mathrm{cm})$, mean \pm SD & $166 \pm 9$ & $167 \pm 10$ & $167 \pm 10$ & 0,783 \\
\hline Weight (kg), mean \pm SD & $76,3 \pm 17,6$ & $76,7 \pm 15,5$ & $78,5 \pm 20,5$ & 0,862 \\
\hline \multicolumn{5}{|l|}{ Education status, n(\%) } \\
\hline Illiterate & $65(20,2)^{\mathrm{a}}$ & $5(7,7)^{\mathrm{a}}$ & $6(8,8)^{\mathrm{a}}$ & \multirow{6}{*}{$<0,001$} \\
\hline Literate & $14(4,3)^{\mathrm{a}}$ & $1(1,5)^{\mathrm{a}}$ & $0(0)^{\mathrm{a}}$ & \\
\hline Elementary school & $180(55,9)^{\mathrm{a}}$ & $38(58,5)^{\mathrm{a}}$ & $29(42,6)^{\mathrm{a}}$ & \\
\hline Junior high school & $24(7,5)^{\mathrm{a}}$ & $8(12,3)^{a}$ & $11(16,2)^{\mathrm{a}}$ & \\
\hline High school & $25(7,8)^{\mathrm{a}}$ & $8(12,3)^{\mathrm{a}}$ & $9(13,2)^{\mathrm{a}}$ & \\
\hline University & $14(4,3)^{\mathrm{a}}$ & $5(7,7)^{\mathrm{a}, \mathrm{b}}$ & $13(19,1)^{\mathrm{b}}$ & \\
\hline \multicolumn{5}{|l|}{ Marital status, n(\%) } \\
\hline Never married & $9(3,6)^{\mathrm{a}}$ & $3(5,9)^{\mathrm{a}, \mathrm{b}}$ & $8(16)^{b}$ & \multirow{3}{*}{0,004} \\
\hline Married & $200(80)^{\mathrm{a}}$ & $43(84,3)^{\mathrm{a}}$ & $39(78)^{\mathrm{a}}$ & \\
\hline Widow & $41(16,4)^{\mathrm{a}}$ & $5(9,8)^{\mathrm{a}}$ & $3(6)^{\mathrm{a}}$ & \\
\hline
\end{tabular}




\begin{tabular}{|c|c|c|c|c|}
\hline \multicolumn{5}{|l|}{ Home partner status, n(\%) } \\
\hline Lives alone & $20(8)$ & $2(3,9)$ & $1(2)$ & \multirow{6}{*}{ NA } \\
\hline Lives with partner & $43(17,3)$ & $6(11,8)$ & $7(14)$ & \\
\hline Lives with partner and children & $145(58,2)$ & $36(70,6)$ & $29(58)$ & \\
\hline Lives with children & $19(7,6)$ & $2(3,9)$ & $1(2)$ & \\
\hline Lives with parents & $10(4)$ & $2(3,9)$ & $3(6)$ & \\
\hline Other (Carer) & $12(4,8)$ & $3(5,9)$ & $9(18)$ & \\
\hline \multicolumn{5}{|l|}{ Settlement unit, n(\%) } \\
\hline Rural & $153(46,8)^{\mathrm{a}}$ & $34(52,3)^{\mathrm{a}}$ & $21(30,4)^{b}$ & \multirow{2}{*}{0,021} \\
\hline Urban & $174(53,2)^{\mathrm{a}}$ & $31(47,7)^{\mathrm{a}}$ & $48(69,6)^{b}$ & \\
\hline \multicolumn{5}{|l|}{ Working status, n(\%) } \\
\hline Working & $47(18,7)^{\mathrm{a}}$ & $12(23,1)^{\mathrm{a}}$ & $21(42)^{b}$ & \multirow{4}{*}{$\mathbf{0 , 0 3 1}$} \\
\hline Not working & $111(44)^{\mathrm{a}}$ & $22(42,3)^{\mathrm{a}}$ & $15(30)^{\mathrm{a}}$ & \\
\hline Retired & $75(29,8)^{\mathrm{a}}$ & $13(25)^{\mathrm{a}}$ & $12(24)^{\mathrm{a}}$ & \\
\hline Other (irregular business) & $19(7,5)^{\mathrm{a}}$ & $5(9,6)^{\mathrm{a}}$ & $2(4)^{\mathrm{a}}$ & \\
\hline \multicolumn{5}{|l|}{ Visual impairment, n(\%) } \\
\hline No & $117(47,8)$ & $22(55)$ & $22(64,7)$ & \multirow{2}{*}{0,149} \\
\hline Yes & $128(52,2)$ & $18(45)$ & $12(35,3)$ & \\
\hline \multicolumn{5}{|l|}{ Kidney disease etiology, n(\%) } \\
\hline $\mathrm{DM}$ & $135(41,2)^{\mathrm{a}}$ & $23(35,9)^{\mathrm{a}}$ & $17(24,6)^{b}$ & \multirow{4}{*}{$\mathbf{0 , 0 1 4}$} \\
\hline HT & $66(20,1)^{\mathrm{a}}$ & $19(29,7)^{\mathrm{a}}$ & $16(23,2)^{\mathrm{a}}$ & \\
\hline PKD & $33(10,1)^{\mathrm{a}}$ & $4(6,3)^{\mathrm{a}}$ & $3(4,3)^{\mathrm{a}}$ & \\
\hline Others & $94(28,7)^{\mathrm{a}}$ & $18(28,1)^{\mathrm{a}}$ & $33(47,8)^{b}$ & \\
\hline \multicolumn{5}{|l|}{$\begin{array}{l}\text { Family history of kidney disease, } \\
\text { n(\%) }\end{array}$} \\
\hline Yes & $34(10,3)$ & $5(7,8)$ & $2(2,9)$ & \multirow{2}{*}{0,135} \\
\hline No & $295(89,7)$ & $59(92,2)$ & $67(97,1)$ & \\
\hline $\begin{array}{l}\text { Number of people living at home, } \\
\text { median (min-max) }\end{array}$ & $3(1-11)$ & $3(1-5)$ & $4(1-11)$ & 0,309 \\
\hline $\begin{array}{l}\text { Predialysis educating period } \\
\text { (month), median (min-max) }\end{array}$ & $17(1-108)$ & $15,6(1-72)$ & $12(1-64,8)$ & 0,258 \\
\hline \multicolumn{5}{|l|}{ Number of annual follow up, $n(\%)$} \\
\hline$<3$ & $76(23)$ & $17(26,2)$ & $17(24,6)$ & \multirow{2}{*}{0,847} \\
\hline$>=3$ & 254(77) & $48(73,8)$ & $52(75,4)$ & \\
\hline $\begin{array}{l}\text { Modified charlson comorbidity index } \\
\text { score, median (min-max) }\end{array}$ & $5(1-11)^{\mathrm{a}}$ & $4(2-9)^{b}$ & $2(2-8)^{c}$ & $<0,001$ \\
\hline
\end{tabular}

\section{Discussion}

Patients with ESRD who need RRT make compelling treatment decisions. It must be admitted that there is no single perfect form of RRT. Since each of the available options has its own strengths and limitations, it is important to know the factors that affect this choice in order to minimize the complexity of the choice of the patient and the clinician and the level of decision conflict during the selection of the RRT method.

The most common type of treatment used as RRT in our country and in the world is HD $(5,18)$. While kidney transplantation is associated with the best survival, there are limitations due to lack of donor kidney. It has 
been reported that the number of patients undergoing $\mathrm{PD}$ is increasing in many countries with developing health care economies (7). According to the Turkish Society of Nephrology 2020 data in our country, the rates of RRT patients were reported as $78 \% \mathrm{HD}$, PD $10.13 \%$, and $\mathrm{RT}$ $11.56 \%$. It has been reported that there has been a slight increase in the number of patients undergoing PD in the last 2 years (19). In our study, there were 330 (71.1\%) patients who chose HD, 65 (14\%) patients who chose PD, and 69 (14.9\%) patients who chose RT. Our findings are compatible with the literature, but it is seen that there are PD patients in our center above the average of our country. The reason for this situation may be that predialysis educating program is applied to patients in our center. Indeed, there are publications reporting that pre-dialysis education programs increase the choice of home based treatments, including PD $(20,21)$.

Although age is not a criterion for choosing RRT, most elderly patients who require RRT choose HD (22). It has been reported that HD is a preferred method of RRT because it provides ongoing medical treatment and follow up for elderly patients, and also provides an opportunity to socialize during treatments in the center $(23,24)$. PD has been underused for many reasons, including financial, cultural issues, limited accessibility, and lack of familiarity with the care of elderly patients.

It has also been reported that PD is less preferred in these patients because of decreased vision, strength, dexterity, and cognitive impairments (25). In one study, it was stated that one-third of elderly patients chose PD before HD in the absence of contraindications (26). It has been reported that age is not a contraindication for RT, another RRT treatment, and it can be performed at any age, but age related comorbidity is an important limiting factor (27). Although it is said that RT can be performed at any age, it has been reported that the cases are concentrated in the young age group such as 20-44 years (28). In our study, it was observed that the mean age of the HD group was higher than the other two groups, and the mean age of the patients in the PD group was significantly higher than in the RT group. With these findings, results similar to the literature were obtained.

In the studies conducted, it was stated that while there were more patients in the HD group who were uneducated or not primary school graduates, the rate of higher education was higher in the RT group. It has been reported that the rate of working in a job is higher in RT patients, and the rate of retiring or not working in a job is higher in HD and PD patients $(29,30)$. In the same studies, marital status, the rate of unmarried RT patients was found to be higher than HD and PD patients. In another study, no statistical difference was found between the three RRT modalities in terms of living in urban and rural areas (31). In our study, it was found that the percentage of being a university graduate and never married in RT patients was higher than the HD group in terms of educational status. The percentage of patients in the RT group living in an urban area and working at a job was found to be higher than the other two groups. In this case, it can be said that patients with a high literacy rate, actively working and living in the urban area prefer RT more.

Among the causes leading to chronic renal failure, DM and HT have been reported to be the leading etiological factors $(32,33)$. In a study by Alvares et al., in which three RRTs were compared, comorbid diseases were examined. Accordingly, it has been reported that $\mathrm{DM}$ is observed at a higher rate in $\mathrm{PD}$ patients than in HD and RT patients (34). In other studies, it has been reported that patients with malignancy or DM prefer HD as the initial treatment more than PD (35). In our study, the DM rate of patients who chose HD and PD was found to be similar. While the rate of kidney etiology being DM was lower in RT patients than the other two groups, it was observed that the rate of being in other CKD etiologies was higher. The emergence of complications such as kidney failure at older ages and the fact that RT is preferred in younger patients may be an explanation for why DM is less common in patients who prefer RT.

There are studies examining the differences of comorbidity between modalities. In the study 
of Chen et al., it was reported that the comorbidity index was higher than the control group and the index was in the form of HD, PD, RT (36). In another study, the highest comorbidity index was observed in PD patients, while the lowest was observed in RT patients (34). In our study, when the modified charlson comorbidity index scores of the groups were examined, it was determined that the highest values were in the HD group and the lowest values were in the RT group. Similar to the literature, the reasons for the low comorbidity index of RT patients may be that younger patients prefer this treatment and that diseases that contribute to comorbidity such as DM are less common in the etiology of kidney disease in RT patients.

We think that this study, which analyzes the factors affecting the choice of RRT, is important for clinicians to know the factors that may affect the patient's choice of RRT, and to guide the patients correctly during the treatment selection after a rigorous educating process during the predialysis period, considering these factors. Because We believe that our study is a comprehensive and guiding study that can answer the question of "which treatment is better?" by patients and can guide clinicians to understand the point of view of patients.

\section{REFERENCES}

1. Levey AS, Coresh J. Chronic kidney disease. Lancet. 2012; 14;379:165-80.

2. Bikbov B, Purcell CA, Levey AS, et al. Global, regional, and national burden of chronic kidney disease, 1990-2017: a systematic analysis for the Global Burden of Disease Study 2017. Lancet. 2020; 395: 70933.

3. Süleymanlar G, Utaş C, Arinsoy T, et al. A population-based survey of Chronic REnal Disease In Turkey--the CREDIT study. Nephrol Dial Transplant. 2011; 26:1862-71.

4. Foley RN, Collins AJ. End-stage renal disease in the United States: an update from the United States Renal Data System. J Am Soc Nephrol. 2007; 18: 2644-48

5. National Institutes of Health. "National Institute of Diabetes and Digestive and Kidney Diseases. United states renal data system." 2018 USRDS annual data report: Epidemiology of kidney disease in the united states., bethesda, MD (2018).
Among the limitations of our study; It can be shown as a single centre, quality of life according to the selected RRT, not doing the treatment satisfaction questionnaire, not considering the hospitalization and mortality rates.

\section{Conclusion}

In our center, where we implemented a predialysis educating program, we saw that there were PD patients above the country average. We have seen that PD treatment and transplantation is preferred in younger patients with less comorbidity, in patients living in urban areas, university graduates, working and unmarried patients. These results show that the sociodemographic characteristics and comorbid conditions of the patients are effective in the choice of treatment modality. Informative education should be given on the pros and cons of modalities in order to facilitate the choice of treatment modality before RRT. In addition to informative education, the most effective treatment modality should be chosen within the framework of the cooperation of the patient, physician and educating nurse, considering the sociodemographic characteristics and comorbid conditions that may affect the choice of the patients.

6. Saran R, Robinson B, Abbott K, et al. United States renal data system. 2016 USRDS annual data report: Epidemiology of kidney disease in the United States. National Institutes of Health, National Institute of Diabetes and Digestive and Kidney Diseases, Bethesda, MD, 2016.

7. Jain AK, Blake P, Cordy $\mathrm{P}$, et al. Global trends in rates of peritoneal dialysis. $J \mathrm{Am} \mathrm{Soc}$ Nephrol. 2012;23:533-544

8. Chaudhary K, Sangha H, Khanna R. Peritoneal dialysis first: rationale. Clin J Am Soc Nephrol. 2011;6:447-456.

9. Fenton SS, Schaubel DE, Desmeules M, et al. Hemodialysis versus peritoneal dialysis: a comparison of adjusted mortality rates. $\mathrm{Am} \mathrm{J}$ Kidney Dis. 1997;30:334-342.

10. Jaar BG, Coresh J, Plantinga LC. Comparing the risk for death with peritoneal dialysis and hemodialysis in a national cohort of patients with chronic kidney disease. ACC Curr J Rev. 2005;14:7-7. 
11. Dahlerus C, Quinn M, Messersmith E, et al. Patient perspectives on the choice of dialysis modality: results from the Empowering Patients on Choices for Renal Replacement Therapy (EPOCH-RRT) study. Am J Kidney Dis. 2016; 68:901-10.

12. Nissenson AR, Prichard SS, Cheng IK, et al. Non-medical factors that impact on ESRD modality selection. Kidney Int. 1993; 40: S120-S127.

13. Mendelssohn DC, Mullaney SR, Jung B, et al. What do American nephologists think about dialysis modality selection? Am J Kidney Dis. 2001; 37:22-29.

14. Merkus MP, Jager KJ, Dekker FW, et al. Quality of life in patients on chronic dialysis: Self-assessment 3 months after the start of treatment. The Necosad Study Group. Am $J$ Kidney Dis. 1997; 29:584-92.

15. Golper TA, Vonesh EF, Wolfson M, et al. The impact of pre-ESRD education on dialysis modality selection. J Am Soc Nephrol. 2000; 11:231A.

16. Levey AS, Stevens LA, Schmid CH, et al. A new equation to estimate glomerular filtration rate. Ann Intern Med. 2009; 150:604-12.

17. Beddhu S, Bruns FJ, Saul M, et al. A simple comorbidity scale predicts clinical outcomes and costs in dialysis patients. Am J Med. 2000;108:609-13.

18. Liyanage $T$, Ninomiya $T$, Jha $V$, et al. Worldwide access to treatment for end-stage kidney disease: a systematic review. Lancet. 2015;385:1975-82.

19. Türkiye'de nefroloji, diyaliz ve transplantasyon. Türk Nefroloji Derneği, Registry 2020. Ankara - 2021.

20. Little J, Irwin A, Marshall T, et al. Predicting a patient's choice of dialysis modality: experience in a United Kingdom renal department. Am J Kidney Dis. 2001; 37: 98186.

21. Dimitrios C, Khai N, Bassam F, et al. What influences patient choice of treatment modality at the pre dialysis stage? Nephrol Dial Transplant. 2012; 27: 1542-47.

22. Cohen LM, Ruthazer R, Moss AH, et al. Predicting six-month mortality for patients who are on maintenance hemodialysis. Clin $J$ Am Soc Nephrol. 2010;5:72-9.

23. Brown EA, Johansson L. Dialysis options for end-stage renal disease in older people. Nephron Clin Pract. 2011; 119 (Suppl 1): c10-c13.

24. Franco MR, Fernandes NM. Dialysis in the elderly patient: a challenge of the XXI century-narrative review. $J$ Bras Nefrol. 2013; 35: 132-141.

25. Oliver MJ, Quinn RR. Is the decline of peritoneal dialysis in the elderly a breakdown in the process of care? Perit Dial Int. 2008;28:452-6.

26. Jager KJ, Korevaar JC, Dekker FW, et al. Netherlands Cooperative Study on the
Adequacy of Dialysis (NECOSAD) Study Group. The effect of contraindications and patient preference on dialysis modality selection in ESRD patients in The Netherlands. Am J Kidney Dis. 2004;43:891-9.

27. Knoll G, Cockfield S, Blydt-Hansen T, et al. Canadian Society of Transplantation: consensus guidelines on eligibility for kidney transplantation. CMAJ. 2005;173:S1-S25.

28. Seyani N, Ateş K, Süleymanlar G. Türkiye'de renal replasman tedavilerinin güncel durumu: Türk Nefroloji Derneği kayıt sistemi 2015 yılı özet raporu. Turk Neph Dial Transpl. 2017;26:154-60.

29. Panagopoulou A, Hardalias A, Berati S, et al. Psychosocial issues and quality of life in patients on renal replacement therapy. Saudi $J$ Kidney Dis Transpl. 2009;20:212-8.

30. Niu SF, Li IC. Quality of life of patients having renal replacement therapy. $J A d v$ Nurs. 2005; 51: 15-21.

31. Sayin A, Mutluay R, Sindel S. Quality of life in hemodialysis, peritoneal dialysis, and transplantation patients. Transplant Proc. 2007:39:3047-53,

32. Jha V, Garcia-Garcia G, Iseki K, at al. Chronic kidney disease: global dimension and perspectives. Lancet. 2013;382:260-72.

33. 33.Hart PD, Bakris GL. Hypertensive nephropathy: prevention and treatment recommendations. Expert Opin Pharmacother. 2010;11:2675-86.

34. Alvares J, Cesar CC, Acurcio Fde A, et al. Quality of life of patients in renal replacement therapy in Brazil: comparison of treatment modalities. Qual Life Res. 2012;21:983-91.

35. Couchoud C, Moranne O, Frimat L, et al. Associations between comorbidities, treatment choice and outcome in the elderly with endstage renal disease. Nephrol Dial Transplant. 2007; 3: 27-32.

36. Chen SF, Wang IJ, Lang HC. Risk of major depression in patients with chronic renal failure on different treatment modalities: a matchedcohort and population-based study in Taiwan. Hemodial Int. 2016; 20:98-105. 